\title{
Invasive Plants of Horticultural Origin
}

\author{
Carl E. Bell ${ }^{1}$ and Cheryl A. Wilen ${ }^{2}$ \\ University of California Cooperative Extension, 5555 Overland Avenue, Building 4, San Diego, CA 92123 \\ Alison E. Stanton ${ }^{3}$ \\ University of California, Weed Science Program, Department of Vegetable Crops, Davis, CA 92521
}

People take their useful and ornamental plants, and inadvertently their weeds, with them as they move around the world. This was true for the migrations of ancient peoples, of the colonial European expansion of the early periods of the last millennium, and continues today. When people move from one similar climate zone to another, it is not surprising that the flora they take with them are able to adapt and survive in the new geographical location. The first introductions of European plants into California were by missionaries who settled much of the state for Spain. Since Spain and California both have Mediterranean climates consisting of wet winters and dry summers, many of these introductions have prospered. Examination of adobe bricks from buildings erected in the $18^{\text {th }}$ and $19^{\text {th }}$ centuries in California has revealed seed and pieces of several European weeds such as red-stem filaree (Erodium moscatum), curly dock (Rumex crispus), and annual sowthistle (Sonchus asper) (Tellman, 1996). Giant reed (Arundo donax), which is native to the Middle East, and Peruvian (or California) peppertree (Schinus molle), a South American native, are examples of ornamental plants introduced into California decades before it became a state (Anonymous, 2001).

Weeds are generally accidental introductions to a new location, perhaps through contaminated seed, in soil, in hay, or on some piece of equipment that was moved from one site to another. Their inability to persist on their own away from human disturbance makes them domesticated species and tied closely to human civilization for their survival. Invasive plants can also be accidental introductions, but many were introduced on purpose for their ornamental value or other uses like erosion control, wind breaks, and animal fodder.

We make a distinction between weeds and invasive plants. One way to differentiate weeds from invasive plants is by their ability to invade and naturalize in new sites, or, in other words, to become part of the flora of the site. We borrow the definition of Raven and Axelrod (1978) regarding plants introduced into California and apply it to the rest of North America, that "... they should not be considered part of the flora

\footnotetext{
Received for publication 2 May 2002. Accepted for publication 14 July 2002. This material is based upon work supported by the Cooperative State Research, Education and Extension Service, U.S. Dept. of Agriculture, under special project Section 3(d), Integrated Pest Management.

${ }^{1}$ Regional Advisor-Invasive Plants.

${ }^{2}$ Area Integrated Pest Management Advisor, Univ. of California Statewide IPM Program.

${ }^{3}$ Former Graduate Student.
}

of the State until they have become fully established away from cultivation, or until it is clear they are capable of persisting without human cultivation." Many of the horticultural and agricultural weeds common to human civilization, although competitive and problematic in disturbed sites, are not invasive according to this definition. Others, such as the Brazilian peppertree (Schinus terebinthifolius) in Florida and pampasgrass (Cortaderia sellonana) in coastal California, clearly fit the definition of invasive plants because they are established in natural habitats and are spreading.

In the United States, $85 \%$ of purposeful introductions of non-native plants have been for landscape use (Reichard, 1996). In this context, landscape uses include wildlife habitat creation and soil protection in addition to aesthetic purposes. The great majority of these plants have been environmentally benign, but significant numbers have become invasive. Of the 78 plants considered the most invasive in California (Bossard et al., 2000), 41 were propagated in the state by nurseries as ornamentals and eight were brought in for soil erosion control. In like manner, Randall and Marinelli (1996) describe 80 species that are invasive in a variety of regions throughout the United States; all of these are ornamental plants that have or have had landscape uses. Sixty-five percent of the invasive plants that have naturalized in Australia over the past 25 years were introduced for ornamental purposes (Groves, 1997).

Nongovernmental organizations have been created by people concerned about the effect of invasive plants on natural landscapes in the United States. The oldest of these is the Florida Exotic Pest Plant Council (FLEPPC) founded in 1984. Other EPPCs exist, such as in California and Tennessee, or are in the formation process in several states. These EPPCs, along with native plant societies groups and public agencies have published lists of invasive plants for several states. Table 1 shows the number of plants listed, and the proportion of those that have a horticultural origin, for six such organizations. These lists are not official and do not provide a basis for legal action such as quarantine or eradication programs. We provide this information just to show that invasive plants of horticultural origin are viewed as a problem throughout the United States. These lists are available on the internet.

Ornamental plants sold commercially by nurseries are those that have marketable aesthetic qualities, such as a desirable growth habit, attractive foliage, or flower color. In order to be commercially successful, however, ornamental plants must have agronomic characteristics that make them feasible for nursery production and landscape use. These characters typically include ease of propagation, rapid growth, and disease tolerance. Other useful characters might include drought tolerance, salinity tolerance, or hardiness. Collectively, these characteristics increase the propensity of plants to survive without human assistance and become established in natural habitats. But, garden escapes are regional; not all invasive plants that have escaped into the wild are a problem everywhere they exist as landscape ornamentals. Table 2 lists examples of invasive plants of horticultural origin and the regions where they have been identified as a problem.

Invasive plants and animals are an important environmental issue; they are regarded as the second greatest threat to global biological diversity, ranking only behind outright habitat destruction (Pimm and Gilpin, 1989). It is estimated that nearly $40 \%$ of the species listed as endangered or threatened by the U.S. Dept. of Interior are at risk from alien invaders (Wilcove et al., 1998). Biological impacts of invasive plants are varied. Invasive plants typically are not consumed as readily by native herbivores, both vertebrates and insects. Most native birds do not utilize non-native plants as well as indigenous plants for nesting sites or cover. Native reptiles and small mammals likewise do not generally find these plants as suitable for cover as the native plants. Invasive plants also alter vital ecosystem processes, such as fire, flooding, erosion, sedimentation, and soil salinity.

How might the nursery industry effectively respond to the problem of invasive plants? There are four important issues to consider. Each of these issues will be discussed in more detail.

1) Recognize the importance of the problem to natural landscapes.

2) Recognize that ornamental plant nurseries are involved.

3) Establish meaningful dialogue with public agencies and private groups concerned about invasive plants in order to develop collaborative efforts.

4) Be willing to participate in programs to eliminate or reduce sales of problem species regionally or nationally.

The negative role of invasive plants in natural habitats was brought to the attention of a wider audience in Feb. 1999 when President Clinton issued Executive Order 13112 on invasive species (www.invasivespecies.gov). In this order, the President called upon all federal cabinet level agencies to coordinate their activities to combat invasive alien species, which includes animals as well as plants. Dialog among governmental, scientific, educational, and nursery industry groups is valuable as 


\begin{tabular}{|c|c|c|c|}
\hline $\begin{array}{l}\text { No. of plants } \\
\text { listed }\end{array}$ & $\begin{array}{l}\text { Percent of listed } \\
\text { plants that are of } \\
\text { horticultural } \\
\text { origin }^{z}\end{array}$ & $\begin{array}{c}\text { Nongovernmental } \\
\text { organization }\end{array}$ & $\begin{array}{c}\text { Website where list } \\
\text { is maintained }\end{array}$ \\
\hline$\overline{87}$ & 83 & Florida Exotic Pest Plant Council & http://www.fleppc.org/01list.htm \\
\hline 73 & 60 & California Exotic Pest Plant Council & http://www.caleppc.org \\
\hline 70 & 34 & $\begin{array}{l}\text { Washington Native Plant Society } \\
\text { (list is for Washington and Oregon) }\end{array}$ & http://www.wnps.org/eppclist.html \\
\hline 74 & 58 & Tennessee Exotic Pest Plant Council & http://www.se-eppc.org/doc.cfm?id=473 \\
\hline 86 & 58 & Virginia Native Plant Society & http://www.vnps.org/invasive.html \\
\hline 39 & 54 & Connecticut Geological and Natural History Survey & http://www.eeb.uconn.edu/cipwg \\
\hline
\end{tabular}

${ }^{\mathrm{z}}$ Only those plant names from each list that are in Hortus Third are included as being of horticultural origin (Bailey and Bailey, 1976).

Table 2. Examples of commonly cultivated horticultural plants of that are invasive in different regions of the United States (Bossard et al., 2001; Randall and Marinelli, 1996).

\begin{tabular}{|c|c|c|c|}
\hline $\begin{array}{l}\text { Common } \\
\text { name }\end{array}$ & Botanical name & Area of origin & $\begin{array}{c}\text { States or regions } \\
\text { invaded }\end{array}$ \\
\hline $\begin{array}{l}\text { Giant reed } \\
\text { to }\end{array}$ & Arundo donax & Middle East and Asia & Riparian zones in the "Sun belt" from California \\
\hline Japanese barberry & Berberis thunbergii & Asia & $\begin{array}{l}\text { Maryland } \\
\text { East and Midwest, particularly New York, } \\
\text { New Jersey, and Connecticut }\end{array}$ \\
\hline Pampasgrass & Cortaderia sellonana & South America & California coast \\
\hline Russian olive & Elaeagnus angustafolia & Southern Europe and western Asia & 17 states in the western U.S. \\
\hline Fennel & Foeniculum vulgare & Southern Europe and Mediterranean & Warmer areas of California below $600 \mathrm{~m}$ \\
\hline $\begin{array}{l}\text { English ivy } \\
\text { states }\end{array}$ & Hedera helix & Eurasia & Middle Atlantic, Southeast, and Pacific coast \\
\hline Japanese honeysuckle & Lonicera japonica & East Asia & Eastern half of U.S. \\
\hline Cajeput tree & Melaleuca quinquenervia & Australia and New Guinea & Florida \\
\hline Brazilian peppertree & Schinus terebinthifolius & South America & Florida and riparian areas of southern California \\
\hline Saltcedar & Tamarix ramossissima & Middle East and Asia & Western states, mostly in the arid southwest \\
\hline
\end{tabular}

part of the process of addressing issues 1 and 2. Public awareness of the damaging impacts of invasive plants on natural habitats is still relatively low. Many sectors of the nursery industry, academia, and governmental organizations are not broadly cognizant of this problem or their role in it.

Many managers of public and private lands recognize invasive plants as important factors in degrading their properties. A 1996 poll of National Park Superintendents found that $61 \%$ of 246 respondents indicated non-native plant invasions were moderate or major problems at their parks (Randall, 1996). A majority of Nature Conservancy Stewards polled in 1992 indicated weeds were among their top 10 management problems with $\approx 12 \%$ indicating weeds as their worst problem (Randall, 1996). A workshop held in California on one such invasive plant, saltcedar (Tamarix sp.), attracted attendees from 10 western states (DiTomaso and Bell, 1996).

With increased general awareness of the problem on invasive species, heightened attention will be focused on prevention. An opportunity exists for the nursery industry to take a proactive approach to the problem. The nursery industry, through their associations, such as the American Nursery and Landscape Association, the Florida Nurserymen \& Growers Association (FNGA), and the California Association of Nurserymen (CAN), have started to recognize the problems associated with selling plants that have been shown to invade natural ecosystems.

Some collaborations already exist between the nursery industry, public agencies, and environmental organizations. In Florida, the FNGA, with input from the Florida Exotic
Pest Plant Council, has taken steps to curtail the sale of known invaders by asking their member nurseries to voluntarily eliminate 11 species of ornamentals from their production and sale inventories (Anonymous, 1999). In California, dialogues have taken place on the horticultural origin of invasive plants between the CAN, the California Dept. of Food and Agriculture, and the County Agricultural Commissioners.

Preventing the introduction of new invasive plants is also a difficult and contentious issue. Current federal and state regulations do not mandate any screening process for the invasive potential of imported ornamental plants. A comprehensive Weed Risk Assessment System has been set up by the Australian government using 49 questions in a decision tree to evaluate the potential invasiveness of plants being proposed for introduction into the country (Anonymous, 2000). The Nursery Industry Association of Australia worked with federal, state, and territorial agencies to devise this system (Atkinson, 2000; Walton, 1998). A similar system is being investigated for the United States. The Presidential executive order called for the creation of an Invasive Species Management Plan. This plan, issued in Jan. 2001, requires federal agencies to "develop a fair, feasible, and risk-based comprehensive screening system for evaluating first-time intentionally introduced non-native species" by Dec. 2003. This provision applies to all non-native propagative plants or seeds for any purpose, including horticulture and botanic gardens.

Within the nursery industry, novel plant species or cultivated varieties are considered a key element to stimulating consumer interest. Wholesale nurseries grow plants based upon consumer demand, which is communicated to them principally via retail nurseries. Retail nurseries promote particular plants to customers, but they are also influenced by plant selections made by landscape architects and designers, the gardening media, plant enthusiasts, and botanic gardens. These latter groups seem to have a large impact on introducing new ornamental species, especially "exotic" plants. We do not know of any organized efforts to date to educate these groups about invasive plants and their role in the problem. One valuable part of educational efforts would be to engage these groups in a dialogue about the use of non-invasive or native plants in landscape design.

Once a meaningful dialogue is in place between the nursery industry, environmental organizations, and government agencies about invasive plants, Issue 4: encouraging participation in programs to eliminate or reduce sales of problem species, can be addressed. The examples in Florida and Australia are encouraging and show that compromise and collaboration is possible to address conflicting interests. Although environmental organizations, such as the EPPCs, would like to see problem invasive plant species eliminated from sale, horticulturists are quick to point out the regional nature of many weed problems. The nursery industry is generally opposed to legal or regulatory prohibitions on production and sale of ornamental plants, particularly on a statewide or national basis. Many weeds have restricted distributions and are problems in limited areas. Local restrictions on particular species where they are or likely to be invasive would minimize impacts on the nursery industry and might provide a financially and 
environmentally acceptable compromise.

The complex problem of invasive plants will undoubtedly influence the future of the ornamental nursery industry. An opportunity exists for the nursery and related industries to be proactive on the issue of invasive plants of horticultural origin.

\section{Literature Cited}

Anonymous. 1999. FNGA urges growers to phase out production of 11 invasive plants. Greenline, Aug./Sept. 1999. Florida Nurserymen and Growers Assn.

Anonymous. 2000. The Weed Risk Assessment System. URL: http://www.affa.gov.au/content/ output.cfm?ObjectID=D2C48F86-BA1A11A1-A2200060B0A04014.

Anonymous. 2001. Western garden book. Sunset Publishing Corp., Menlo Park, Calif.

Atkinson, I. 2000. Invasive plants not wanted in public or private gardens identified. The Nursery
Papers, Nursery Industry Assn. of Australia, issue no. 2000/12. URL: http://www.NGIA.com.au/ np/2000No12/00-12.html.

Bailey L.H. and E.Z. Bailey. 1976. Hortus third. Macmillan Publ., New York.

Bossard, C.C., J.M. Randall, and M.C. Horshovsky. 2000. Invasive plants of California's wildlands. Univ. of California Press, Berkeley and Los Angeles.

DiTomaso, J. and C.E. Bell. 1996. Introduction, p. i. In: Proc. of The Saltcedar Management Workshop, 12 June 1996, Rancho Mirage, Calif.

Groves, R. 1997. Recent incursions of weeds to Australia, 1971-1995. Coop. Res. Ctr. for Weed Management Systems.

Pimm, S.L. and M.E. Gilpin. 1989. Theoretical issues in conservation biology, p. 287-305. In: J. Roughgarden, R.M. May, and S.A. Levin (eds.) Perspectives in ecological theory. Princeton Univ. Press, Princeton, N.J.

Randall, J.M. 1996 Weed control for the preservation of biological diversity. Weed Technol. 10:370-383.
Randall, J.M. and J. Marinelli (eds.). 1996. Invasive plants: Weeds of the global garden. Brooklyn Botanic Garden, New York.

Raven, P.H. and D.I. Axelrod. 1978. Origin and relationships of the California flora. Univ. of Calif. Press, Berkeley and Los Angeles.

Reichard, S.E. 1996. Prevention of invasive plant introductions on national and local levels, p. 215-227. In: J.O. Luken and J.W. Thieret (eds.). Assessment and management of plant invasions. Springer-Verlag, New York.

Tellman, B. 1996. Stowaways and invited guests: How some exotic plants reached the American Southwest, p. 10-15 In: Proc. California Exotic Pest Plant Council Symp.

Walton, C. 1998. Preventing the introduction of potential weeds as ornamental plants. The Nursery Papers, Nursery Industry Association of Australia, issue no. 1998/10. URL:http: //www.NGIA.com.au/np/np98 10.html.

Wilcove, D.S., D. Rothstein, J. Dubow, A. Phillips, and E. Losos. 1998. Quantifying threat to imperiled species in the United States. BioScience 